\title{
HOW DO SELECTED DETERMINANTS AFFECT FINANCIAL STRUCTURE IN MANUFACTURING INDUSTRY IN SELECTED COUNTRIES OF CENTRAL AND EASTERN EUROPE
}

\author{
[Jak vybrané determinanty ovlivňují finanční strukturu ve zpracovatelském \\ průmyslu ve vybraných zemích střední a východní Evropy]
}

\author{
Petra Růčková ${ }^{1}$ Nicole Škuláňová ${ }^{2}$ \\ ${ }^{1}$ Silesian University, School of Business Administration, Univerzitni nám. 1934/3, 73340 Karvina \\ Email: ruckova@opf.slu.cz \\ ${ }^{2}$ Silesian University, School of Business Administration, Univerzitní nám. 1934/3, 73340 Karvina \\ Email: skulanova@opf.slu.cz.
}

\begin{abstract}
The topic of financial or capital structure is one of the very important components of corporate finance, as a wrong adjustment of the ratio of own and external sources of financing can lead a company to bankruptcy. This research expands knowledge in the field of manufacturing industry for eight selected economies of Central and Eastern Europe during the years 2009-2018. A total of 92,504 companies are examined. In addition, companies are divided according to size into medium and large. The aim of the research is to find out whether profitability, liquidity, asset structure, non-debt tax shield, GDP, interest rate has an effect on the amount of total, long-term and short-term debt. The dependencies are investigated by panel regression using the Generalized Method of Moments. Unfortunately, due to the large set of data and variables examined, it is impossible to summarize the results for each economy, but it is concluded that external factors have the greatest impact on the indebtedness level of manufacturing companies. Specifically, the development of the economy and the interest rate.
\end{abstract}

Keywords: asset structure, financial structure, GDP, interest rate, liquidity, non-debt tax shield, profitability.

JEL classification: G32

Received: 1.10.2020; Reviewed: 3.11.2020; 27.12.2020; Accepted: 3.11.2021

\section{Introduction}

The concept of capital structure should be familiar to every head of the finance department in each company, as the concern for the capital structure should be one of his key activities. Capital or, in the case of this research, its extension version - financial structure is, in short, all financial resources of the company. Every company, and especially the industry, is differently financially demanding and at the same time the company itself is differently financially demanding during its life cycle.

The theory of corporate finance has been dealing with this issue since the beginning of the last century, and this concept became a more important topic in the middle of the last century. During this period, a major study was created - "The Cost of Capital, Corporation Finance and the Theory of Investment" (Modigliani and Miller 1958). In this study, which marked the beginning of modern corporate finance, the authors dealt with the indebtedness of companies and how it is affected. The idea of "what affects the structure of funding sources and what should be the ratio between own and external resources" has become a much-discussed topic. To date, a great number of studies have been created (and more are still being created) that have tried to find the right answer to these questions. There is still no universal answer, as, by Myers (2001), there are many factors that affect the structure of funding sources. Despite the given amount, the studies have several common characteristics, according to which they are 
divided into several theories of capital structure. The two basic theories are considered to be the trade-off theory (Brealey et al. 2011) and the pecking order theory (Myers 1984).

Although after this brief introduction it might seem that there are already enough studies, the opposite is true. Initial studies of data sources looked at companies, data of which were available, and as a result, large, more listed companies from highly developed economies such as the United States and the United Kingdom were examined. Only with the development of databases and data such studies were elaborated that no longer looked at geographical, size or sectoral affiliation. However, such studies began to emerge around the beginning of the new century, and given the number of economies, industries and companies in the world, there is much room for further research into capital structure.

From the authors' point of view, the still missing study dealing with the economies of Central and Eastern Europe regarding the selected sector is the motivation for this research. Although few studies are devoted specifically to the manufacturing industry, only one (Růčková 2015b) includes the countries of Central and Eastern Europe, namely, the Czech Republic, Poland, Slovakia and Hungary for the period 2006 to 2013, and only profitability and liquidity were examined. In addition, the research did not examine all companies of the database. Further studies focused on Pakistani companies in selected manufacturing sectors for the period 2004-2013 (Rehman 2016) and 2001-2010 (Riaz et al. 2014). The last study (Toy et al. 1974) examined companies from Norway, the Netherlands, the USA, Japan and France in 19721974. Such a short list of studies shows a clear lack of studies considering this sector and examined countries.

The aim of the research is to determine whether profitability, liquidity, asset structure, nondebt tax shield, GDP, and interest rate affect the amount of total, long-term and short-term debt. The benefit of the research should lie primarily in the size of the study sample, which includes over 90,000 companies from eight economies within the manufacturing industry. For each economy, two panels are compiled according to the size of the companies, which in this research are divided into medium and (very) large companies.

This paper is organized as follows. Section 1 outlines earlier studies on the financial structure. Section 2 presents the research methodology, variables and provides a description of the industry and examined economies. Section 3 describes the results of the analysis of variable dependencies. Section 4 presents the conclusions.

\section{Literature overview}

The concepts of capital and financial structure were mentioned in the introduction. Both of these terms are related to financial resources in the company. More specifically, they relate to the right-hand side of the balance sheet in which the sources of funding are located. The difference in these terms is in their composition - the financial structure consists of long-term and short-term sources of financing; the capital structure includes only long-term sources. In addition, taking time in this area into account, we also use the aspect of ownership, which results in the division of sources of financing into own and debt sources. The introduction also stated that the financial structure is affected by a number of factors. These effects can be internal (environment in company) and external (non-corporate environment). This research includes external and internal influences. Specifically, the influence of profitability, liquidity, asset structure, non-debt tax shield, economic development and the development of the basic interest rate at the debt level (of three forms - total, long-term and short-term debt) is examined. In the following paragraphs, earlier studies dealing with these factors will be 
analyzed, which, as the research will show us, can have a positive and negative effect on the indebtedness level.

The relationship between profitability and indebtedness is the first relationship to be examined. This factor belongs to the basic ones and is part of almost all studies dealing with this issue. The positive effect of profitability on the amount of indebtedness is connected with one of the basic theories mentioned in the introduction, namely the trade-off theory. The main idea of this theory is to find the optimal debt level by finding a balance between tax benefits and the cost of financial distress (Brealey et al., 2011). In terms of profitability, the more profitable companies would be the further they would move away from possible bankruptcy. If a company is not above the abyss of bankruptcy and is prosperous, indebtedness may increase. The positive effect has been confirmed in studies by Klapper et al. (2002), Pinková (2012), Aulová and Hlavsa (2013), Mokhova and Zinecker (2013) in Slovenia, Růčková (2015a, 2015b, 2017) in the Czech Republic and Hungary. On the contrary, the negative effect of profitability on the indebtedness level is connected with the second theory - the pecking order theory, the output of which the determination of preferences when it comes to the financing sources is. Myers (1984) stated that companies prefer own sources to external ones. If the profitability of companies increases, so does the possibility of internal financial sources use in the form of retained earnings, for example. Negative effects have been found, for example, Rajan and Zingales (1995), Michaelas et al. (1999), Nivorozhkin (2002, 2005), Bauer (2004), Weill (2004), De Haas and Peeters (2006), Cheng and Shiu (2007), Delcoure (2007), De Jong et al. (2008), Črnigoj and Mramor (2009), Hernádi and Ormos (2010, 2012 ), Hanousek and Shamshur (2011), Kayo and Kimura (2011), Mateev et al. (2012), Jõeveer (2013), Mokhova and Zinecker (2013) except Slovenia, Prędkiewicz and Prędkiewicz (2015), Růčková $(2015 b, 2017)$ in Poland and Slovakia.

The impact of the asset structure depends on the selection of such a variable representing this factor. In this research, it will be the share of tangible fixed assets and total assets. Tangible assets are assets that can be used as a collateral, such as a real estate. As a result of this choice, according to the studies, a positive impact on the level of long-term debt and a negative impact on the level of short-term debt is expected. Intangible assets cannot be used as a collateral and are very difficult to sell in the event of financial problems, and above all with a large loss (Titman and Wessels 1988). There could be a discrepancy in this research, as there are several pitfalls for this factor, one of which is important for this research. Companies in the manufacturing industry could have a certain level of inventory that cannot be used as a collateral for long-term debt, and this could have a negative impact (Růčková 2015a). Positives can be found in studies such as Michaelas et al. (1999), Klapper et al. (2002), Nivorozhkin (2002), Delcoure (2007), De Jong et al. (2008), Hernádi and Ormos (2010, 2012), Kayo and Kimura (2011), Mokhova and Zinecker (2013), Vo (2017). In contrast, the negative impact was revealed by Klapper et al. (2002), Nivorozhkin (2002), Bokpin (2009), Mokhova and Zinecker (2013), Vo (2017). It always depends on a specific sample of companies, industries, composition of assets, etc. Unfortunately, there is no room to deal with each study and interpret its results. This summary is only intended to show us that we cannot say unequivocally that liquidity has, for example, a positive impact.

A company's liquidity means its solvency - whether it is able to meet its liabilities in case they have to be repaid. Liquid assets are those that can be sold almost immediately. In contrast, illiquid assets are very difficult to sell and the seller often has to lower the price in order to get a buyer at all. As such, liquid assets should be acquired through debt financing and illiquid assets from own financial resources. This justifies a positive link between 
liquidity and debt levels. A positive impact has been found in studies by, for example, Williamson (1988), Shleifer and Vishny (1992), Mateev et al. (2012) for long-term debt, Růčková (2015b) for the Czechia. The negative impact of liquidity on the amount of indebtedness is explained through a possible conflict between managers and owners. If managers were given the right to dispose of their assets arbitrarily, they could gradually expropriate the owners through the sale of assets. The negative impact was confirmed by the results of studies by Myers and Rajan (1998), Morellec (2001), Frieder and Martell (2006), De Jong et al. (2008), Lipson and Mortal (2009), Mateev et al. (2012) for short-term debt, Pinková (2012), Aulová and Hlavsa (2013), Onofrei et al. (2015), Růčková (2015b) for Poland and Slovakia, Vo (2017).

The non-debt tax shield or depreciation should replace the advantages of the tax shield and reduce the amount of indebtedness compared to it. The negative relationship between these variables has been confirmed in studies by, for example, Michaelas et al. (1999) for long-term debt, Wald (1999), Klapper et al. (2002), Song (2005) for long-term debt, Hernádi and Ormos (2012), and Acedo-Ramírez and Ruiz-Cabestre (2014). The positive relationship between the variables can be explained in two ways, either the value of depreciation and tangible assets is almost the same or there may be differences in the tax regulations in the given countries. A positive relationship has been found in studies such as Delcoure (2007), Hernádi and Ormos (2010), Aulová and Hlavsa (2013) and Mokhova and Zinecker (2013).

The impact of economic development on the debt level is explained by the economic cycle. The positive impact of GDP developments on debt levels means that variables are moving in the same direction. It is therefore clear that if the economy is thriving, it is expanding, all economic entities are in an optimistic mood, companies are growing in profits, and creditors are willing to lend. On the contrary, in a time of recession, everything is the other way around. The positive impact was confirmed in studies by e.g. Gajurel (2006) for long-term debt, Hanousek and Shamshur (2011), Salehi and Manesh (2012), Çekrezi (2013), Mursalim and Kusuma (2017) for Malaysia, Yinusa et al. (2017). The economic cycle also explains the negative impact of GDP. When the economy is in expansion, the profitability of companies usually increases creating a cheap own source of financing. The negative impact was confirmed, for example, by Cheng and Shiu (2007), Bastos et al. (2009), Bokpin (2009), Jõeveer (2012), Mursalim and Kusuma (2017) for Indonesia.

The external financing sources price or the level of the basic interest rate should have a clear impact, namely, the higher interest rates the more expensive the financing sources and the lower the debt will be, and vice versa. Unfortunately, another explanation can be found for this variable bringing another expected impact. Yinusa et al. (2017) in their study states the influence of the quality of the institutional, legal and regulatory environment and for this variable, introduces the division of economies into developed and developing ones. As a result, developed economies have a high-quality institutional environment, good creditor protection and, for example, legal enforcement of liabilities, etc., while developing economies may lack quality in these areas. It follows that developed economies should have a positive impact and developing economies have a negative impact of the level of basic interest rate on the level of indebtedness.

\section{Data and methodology}

This research deals with companies belonging to a sector designated in the NACE classification as Section C - Manufacturing. The companies come from eight selected economies of Central and Eastern Europe; at the same time, these are economies belonging to 
the so-called extended Visegrád Group. Specifically, these are the Czech Republic (CZ), Slovakia (SK), Poland (PL), Hungary (HU), Austria (AT), Slovenia (SI), Romania (RO), Bulgaria (BG). Representatives of the last four countries often take part in the V4 negotiations and therefore often join this group. Eight economies were selected due to a lack of studies within these economies for the selected sector.

The examined sample includes all companies of the Orbis database belonging to the industry. The sample contains a total of 92,054 companies, of which 76,810 are medium-sized companies and 15,244 are large and very large companies (size according to the Orbis database). The financial series for macroeconomic variables come from the World Bank and national central banks' databases. The research is carried out for the period 2009-2018.

Manufacturing in selected economies contributes to $\mathrm{GDP}^{1}$ creation in the range of 14-23\% (CZ $23 \%$, SK $19 \%$, PL $17 \%$, HU $19 \%$, AT $17 \%$, SI $20 \%$, BG $14 \%$, RO $19 \%$ ). It is therefore an important sector in these economies, which is divided into 24 subsectors being very diverse and costly and labour-intensive. On average, in selected economies, $30 \%$ of employees $^{2}$ from the entire non-financial sector work in this sector. The Figure 1 shows the overview of companies by sub-sectors, conclusion of which is as follows:

- In the Czech Republic, Slovakia, Hungary, Austria and Slovenia, most companies are engaged in the manufacture of fabricated metal products subsector, except machinery and equipment.

- In Poland and Romania, most companies are in the manufacture of food products subsector.

Figure 1: Number of companies in individual subsectors in individual countries

\begin{tabular}{|c|c|c|c|c|c|c|c|c|}
\hline & $\mathrm{CZ}$ & SK & PL & HU & AT & SI & BG & RO \\
\hline \multicolumn{9}{|l|}{ Manufacture } \\
\hline of food products & 1878 & 558 & 6077 & 1185 & 973 & 171 & 1348 & 1977 \\
\hline of beverages & 348 & 100 & 286 & 207 & 156 & 24 & 159 & 155 \\
\hline of tobacco products & 5 & 3 & 16 & 5 & 2 & 0 & 13 & 8 \\
\hline of textiles & 373 & 102 & 786 & 175 & 168 & 56 & 149 & 329 \\
\hline of wearing apparel & 1305 & 188 & 2246 & 284 & 107 & 39 & 1646 & 1481 \\
\hline $\begin{array}{l}\text { of leather and related products } \\
\text { of wood and of products of wood and }\end{array}$ & 120 & 83 & 455 & 125 & 47 & 19 & 237 & 589 \\
\hline $\begin{array}{l}\text { cork, except furniture; of articles of } \\
\text { straw and plaiting materials }\end{array}$ & 1373 & 366 & 1975 & 284 & 444 & 184 & 381 & 806 \\
\hline of paper and paper products & 294 & 67 & 744 & 171 & 113 & 46 & 175 & 182 \\
\hline $\begin{array}{l}\text { Printing and reproduction of recorded } \\
\text { media }\end{array}$ & 769 & 108 & 808 & 238 & 279 & 77 & 169 & 240 \\
\hline of coke and refined petroleum products & 16 & 17 & 88 & 4 & 11 & 2 & 7 & 26 \\
\hline of chemicals and chemical products & 384 & 152 & 893 & 202 & 185 & 72 & 166 & 215 \\
\hline $\begin{array}{l}\text { of basic pharmaceutical products and } \\
\text { pharmaceutical preparations }\end{array}$ & 57 & 19 & 156 & 58 & 96 & 9 & 26 & 69 \\
\hline of rubber and plastic products & 1073 & 369 & 2416 & 575 & 389 & 217 & 417 & 614 \\
\hline of other non-metallic mineral products & 793 & 227 & 1675 & 313 & 466 & 95 & 315 & 488 \\
\hline of basic metals & 306 & 99 & 511 & 114 & 157 & 46 & 96 & 151 \\
\hline $\begin{array}{l}\text { of fabricated metal products, except } \\
\text { machinery and equipment }\end{array}$ & 4673 & 1062 & 4364 & 1519 & 1464 & 576 & 717 & 1359 \\
\hline $\begin{array}{l}\text { of computer, electronic and optical } \\
\text { products }\end{array}$ & 417 & 120 & 521 & 258 & 306 & 77 & 124 & 203 \\
\hline of electrical equipment & 1182 & 192 & 715 & 253 & 226 & 101 & 177 & 257 \\
\hline of machinery and equipment n.e.c. & 1420 & 365 & 1426 & 535 & 751 & 210 & 354 & 427 \\
\hline $\begin{array}{l}\text { of motor vehicles, trailers and semi- } \\
\text { trailers }\end{array}$ & 483 & 184 & 634 & 225 & 135 & 62 & 53 & 268 \\
\hline of other transport equipment & 168 & 28 & 303 & 43 & 54 & 15 & 37 & 220 \\
\hline of furniture & 657 & 161 & 1845 & 240 & 416 & 110 & 333 & 655 \\
\hline Other manufacturing & 933 & 83 & 751 & 195 & 222 & 49 & 128 & 199 \\
\hline $\begin{array}{l}\text { Repair and installation of machinery and } \\
\text { equipment }\end{array}$ & 1403 & 216 & 1267 & 218 & 189 & 117 & 262 & 234 \\
\hline Total number of companies & 20430 & 4860 & 059 & 7426 & 7356 & 2374 & & 1115 \\
\hline
\end{tabular}

Source: author's calculations based on data from Orbis database

Bulgaria is dominated by the manufacture of wearing apparel subsector.

\footnotetext{
${ }^{1}$ World Bank Open Data [online] [10.9.2020]. Avalaible from https://data.worldbank.org/indicator/NV.IND.MANF.ZS

${ }^{2}$ Eurostat [online] [10.9.2020]. Avalaible from https://ec.europa.eu/eurostat/statistics-explained/pdfscache/10086.pdf
} 
The overview by subsector serves only for the given sector to be characterized; within the panel regression, the sector as a whole is examined in individual countries.

The aim of the research is to find out whether profitability, liquidity, asset structure, non-debt tax shield, GDP, interest rate have an effect on the amount of total, long-term and short-term debt. Within this goal, two research questions were formulated:

- Are there differences in impacts in terms of the different maturities of the used funding sources?

- What is the impact of external financing sources price on the used financing sources?

Due to the literature search of previous studies, we can create assumptions of the resulting relationships for individual determinants and thus specify research questions. The examined companies belong to the group of medium and large companies, so there is no need to divide the assumptions of impacts of selected determinants on the level of indebtedness according to the size of the companies, as there should be no difference between these companies. In terms of profitability, liquidity, non-debt tax shield and basic interest rate, these variables can be expected to have a negative impact on the indebtedness level in all forms. This means that if these variables increase, debt should decline. The structure of assets and the development of GDP should have a positive impact on the level of long-term debt and a negative impact on the level of short-term debt.

\subsection{Methodology}

For the analysis of the individual determinants impacts on the debt level, only one method was selected, namely, panel regression with respect to the number of companies, economies and variables. Unfortunately, the least squares method is not a completely suitable method, as it requires longer time series, and especially stationary data. However, the assumption of stationarity may limit the use of some time series, e.g. non-corporate data such as GDP growth rate, inflation rate, etc. (Průcha 2014) For a number of reasons, a two-stage system Generalized Method of Moments (GMM) was eventually chosen, the development of which had a major impact on research in finance. GMM overcomes a number of limitations of other methods. For example, we do not have to make distribution assumptions - variables can show serial correlation and conditional heteroskedasticity. (Jagannathan et al. 2002)

Arellano and Bond (1991), Arellano and Bover (1995), Blundell and Bond (1998) dealt with the GMM model in their studies. From these studies, general assumptions for this model emerged - short time series with many observations, linear functional relationship, one endogenous variable on the left side, which is dynamic depending on its past values, exogenous variables, which may not be strictly exogenous (correlation with past or current errors), fixed individual effects and said autocorrelation and heteroskedasticity within individual observations, but not across them. The GMM model thus solves the endogeneity problem, which means the correlation between the explanatory variable and the error term. (Roodman 2009) The GMM system uses several internal tools (lagged value of a dependent variable, internal transformation processes) to address unobserved heterogeneity, simultaneity and dynamic endogeneity, which are sources of endogeneity. (Ullah et al. 2018)

Since the GMM model cannot test the heteroskedasticity and autocorrelation of variables, it is necessary to test whether the set model is correct and whether the instruments have been specified correctly. There are several tests. In this research, the Sargan test is used to show whether we achieve the same results with a slight change in parameters. If its final value is higher than 0.05 , the model was constructed correctly and we can interpret its results. (Ullah et al. 2018) 
The equation for this research looks like this:

$$
\begin{gathered}
D E R_{i t}=\alpha_{0}+\beta_{1} * D E R_{i t}+\beta_{2} * R O A_{i t}+\beta_{3} * L 2_{i t}+\beta_{4} * S A_{i t}+\beta_{5} * N D T S_{i t}+\beta_{6} * G D P_{i t}+\beta_{7} \\
* I R_{i t}+\varepsilon_{i t}
\end{gathered}
$$

where the endogenous variable is indebtedness in three forms (DER $\left.\mathrm{Dit}_{\mathrm{it}}, \mathrm{DER} \_\mathrm{L}_{\mathrm{it}}, \mathrm{DER} \_\mathrm{S}_{\mathrm{it}}\right)$, where DER denotes the debt-to-equity ratio for the $\mathrm{i}$-th number of companies in a given economy in a particular sector during period t (2009-2018). The right side of the equation consists of individual determinants (ROA, L2, SA, NDTS, GDP, IR) and components of the model - annual lagged debt value, constant $\alpha$ and the so-called random component $\varepsilon$, which includes all other factors that affect the debt level.

\subsection{Variables}

Since the method is used regression, we can divide the variables into exogenous and endogenous. In our case, the endogenous variable is the indebtedness of companies represented by the debt-equity ratio. With regard to the research aim, this indicator takes three forms, namely total debt (DER = ratio of total liabilities to equity), long-term debt (DER_L = ratio of long-term liabilities to equity) and short-term debt (DER_S = ratio of short-term liabilities to equity).

Exogenous variables are factors of our choice that affect the financial structure of companies. Profitability takes the form of the ROA indicator - the share of profit before tax and interest and total assets. The indicator L2 (quick ratio) was selected from possible liquidities - the ratio of current assets without inventories and short-term liabilities. The structure of assets (SA) can also be expressed in several ways. In this research, it is the share of tangible fixed assets and total assets. The non-debt tax shield (NDTS) is represented by the ratio of depreciation and total assets. The last two variables represent the external environment of companies - the rate of GDP growth at market prices and the basic interest rate (IR) of the economy.

\subsection{Economic development of individual economies during examined period}

This subchapter deals with the analysis of economic development of selected economies during the period 2009 to 2018 . It should be noted that the characteristics of development will be very brief, as detailed events are important in interpreting the results, and if the coefficients are not statistically significant for the economy. Detailed description is irrelevant.

At the beginning, it is worth noting that the observed ten-year period was relatively loaded with significant economic events. The beginning of the period is connected with the global financial crisis, which in Europe turned into a European debt crisis. This crisis in 2012/2013 was exacerbated by the global economic slowdown and global demand fell at the end of the period. In addition to these common events, each of the selected economies had also its internal problems and crises.

The selected economies can basically be divided into two groups - one that was hit hard by the initial crisis and the other that was hit slightly or not at all by the mentioned events. The second group includes Poland, Bulgaria, the Czech Republic, Austria and Slovakia. The Polish economy, as one of the few in the world during the whole period, did not experience an economic downturn and grew at a very good pace throughout. The Bulgarian and Slovak economies were affected by the financial crisis, but not significantly, and grew by $2.5 \%$ per year on average except in 2009. The Czech Republic recorded a decline in 2009 and 2012/2013, when household consumption and investment fell in particular. In Austria, the 
development of basic economic indicators was not favorable, but apart from the introduction of a deposit guarantee, the economy was no longer limited.

The first group includes Hungary, Romania and Slovenia. The first two economies were hit so hard by the financial crisis that local governments had to apply for an international loan. In Romania, the loan served to kick-start the credit market as well as to strengthen foreign exchange reserves. The Hungarian economy has made up for the poor management of the government and the orientation of the loans that people and businesses took in foreign currencies, which strengthened against the forint during the crisis. The last country is Slovenia, which has gone through the same crisis as the United States (real estate and mortgage crises) and subsequently, unfortunately, was still hit by the banking crisis. However, the government managed all these woes on its own and stabilized the economy.

\section{Results and discussion}

Before interpreting and analysing the results of the panel regression, it is important to mention the form of several variables - the form of indebtedness and the representation of tangible fixed assets and depreciation in total assets. In terms of the amount of indebtedness, for both types of companies, indebtedness slightly outweighs equity in the capital structure. For medium-sized companies, it is on average 57:43, for large companies, it is on average 53:47. Of course, if we look at the individual countries, there are differences. In Czech companies, the share is identical, in which, on the contrary, equity predominates debt (52:48). Furthermore, for large Polish companies, equity predominates (51:49) and for Hungarian large companies, it is even balanced (50:50). The most indebted are medium-sized Slovak, Austrian and Romanian companies $(63 / 64 \%$ of liabilities in the balance sheet are foreign sources) and large Romanian companies (61\%).

The theoretical basis of the manufacturing industry was analysed and it was mentioned that due to their nature, companies could theoretically have a significant number of inventories in this industry, which resulted in more short-term liabilities than long-term liabilities. In the analysis of assets, it was found that on average $18 \%$ for medium-sized companies and $16 \%$ for large companies, inventories are represented in assets. These numbers are not very small being reflected on the debt composition, in which, mainly in Austrian companies, short-term liabilities dominate though. For medium-sized companies, it is on average 70:30 and for large companies it is on average 71:29.

As for the share of tangible assets to total assets, again the shares do not differ much on average. Medium-sized companies possess of $41 \%$ of these assets and large companies $39 \%$ on average. Also, in the case of the share of depreciation to total assets, the shares are very similar $-4 \%$ for medium-sized companies and $5 \%$ for large companies.

In Figures 2 and 3, we can observe the results of panel regression using the GMM method for companies of both sizes. At first sight, the figures do not include results for all eight economies. In the theoretical part, the Sargan test was mentioned, which serves to be able to trust the results of the GMM method. Economies that we do not see in the figures did not pass this test - they did not exceed the limit of 0.05 . The total values of total indebtedness of medium-sized companies were: SK 0.000, AT 0.034, SI 0. 027; for long-term debt: PL 0.015, HU 0.032, SI 0.000, RO 0.003; for short-term debt: CZ 0.046, SK 0.000, AT 0.041, BG 0.018. For the total indebtedness of large companies, the following values were: $\mathrm{CZ} 0.006, \mathrm{PL}$ 0.038, SI 0.002, RO 0.019; for long-term debt: SK 0.045, AT 0.010, BG 0.033; for short-term debt: CZ 0.041, PL 0.021, RO 0.016. 
In the following paragraphs, the individual determinants for individual companies will be analysed according to the size, however, the results of the two factors can be summarized beforehand, as their coefficients reach very low values (tenths, hundredths and thousandths) and there is basically no significant effect on the debt level. The first factor is the lagged value of debt and liquidity. Regarding the relationship between current and past debt, a positive relationship slightly prevails for both types of companies. Given the size of the coefficients, we can only talk about an indication of this variable effect. A positive relationship means that if companies have used debt financing in the past, they are likely to continue to use it in subsequent periods and the indebtedness level will increase.

In terms of liquidity, again, both types of companies are clearly dominated by the negative impact on debt. The negative impact may mean that companies do not have highly liquid assets, as these assets are usually acquired on debt. To confirm this statement, it would be appropriate to look at the detailed structure of assets, however, given the size of the coefficients, this variable does not become so important with respect to increasing/decreasing indebtedness to make a detailed analysis.

According to the previous studies, profitability should have a rather negative impact on the indebtedness level. Unfortunately, the positive impact prevails in our research. The negative impact is shown only for the Czech, Austrian and Romanian companies and the results are followed by studies by Bauer (2004), Delcoure (2007), Mokhova and Zinecker (2013) for all countries except Slovenia. The negative impact means that if these companies grow profits, companies should prefer their own internal resources to finance business activities. For the Czech and Romanian companies, the negative impact of profitability is also supported by the negative impact of GDP, which has the same explanation. Usually, in times of economic growth, companies are more profitable, which creates free and cheap funding sources for them. Unfortunately, for the Austrian companies, there is a discrepancy between the coefficients for GDP and for profitability. A negative impact of profitability means the use of own financial sources at higher profitability, while a positive impact of GDP states that if the economy is doing well and companies are doing well, then the use of debt sources of financing is preferred. For the Romania, the GDP outcome is unexpected, as it could be assumed that the debt level will copy the development of the economy, given that Romania was hit hard by the financial crisis and that international loans were needed to kick-start the credit market and strengthen foreign exchange reserves. The Austrian economy has developed relatively stable after the crisis and one could expect an increase in indebtedness with the prosperity of companies. Apart from 2012 and 2013, the Czech economy grew at a very good and sometimes fast pace, which means that companies also did well, preferring to reduce debt, which is appropriate regarding future economic developments, which may bring a crisis.

In the remaining economies, a positive impact was found, which is in line with the results of e.g. Klapper et al. (2002), Pinková (2012), Mokhova and Zinecker (2013) for Slovenia and Růčková $(2015 a, 2015 b, 2017)$ for Hungary. In all cases, the coefficients for profitability are supported by the results for GDP. The explanation for both variables is that in times of economic growth, corporate profits tend to grow, making companies stronger and moving away from the risk of bankruptcy, and converging to a variety of funding sources. The Polish and Bulgarian economies developed at a very fast pace during the period under review, with economies growing by $3.5 \%$ and $2.2 \%$, respectively. These economies have not felt the greater impact of the events mentioned in the previous chapter, so it is not surprising that companies in these economies have made greater use of debt financing for their development. The Slovenian and Hungarian economies are among the economies that experienced adverse 
economic development, especially in the first half of the period under review, and the positive link between debt and GDP is evident as creditor behaviour can be expected to replicate economic developments and public funding will depend on economic development.

The relationship between the structure of assets and the indebtedness level should be positive for long-term indebtedness and negative for short-term indebtedness according to studies such as Michaelas et al. (1999), Klapper et al. (2002), Delcoure (2007), Mateev et al. (2012). A positive relationship should indicate that the more tangible fixed assets a company has, the higher its indebtedness may be, as it will use such assets as a collateral. A pledge is usually used for a long-term debt, while a short-term pledge is usually not used, and therefore, there is usually a negative impact. For total debt, the resulting impact would probably be as the prevailing debt - if short-term debt predominates, a negative influence can be expected. The Figure 2 shows that these results are met by the Czech, Romanian, Slovak, Austrian, Bulgarian and Polish companies. The negative relationship between the total indebtedness and asset structure of Czech and Romanian companies is not surprising with regard to the composition of liabilities, in which short-term indebtedness dominates. They account for 74 $\%$ of short-term liabilities for Czech companies and $66 \%$ for Romanian companies. On the other hand, Romanian companies possess of a relatively large amount of tangible fixed assets (47\% of assets), while Czech companies $36 \%$. For Slovak and Bulgarian companies, shortterm liabilities again prevail (SK $74 \%$, BG $64 \%$ of liabilities) and the positive impact is slightly unexpected. However, Slovak companies possess of $43 \%$ tangible fixed assets of total assets, Bulgarian $39 \%$. These values are relatively high, and as a result, a positive impact of this variable on the level of long-term debt is possible. What was to be expected, is a positive influence for Austrian companies, where long-term liabilities account for $98 \%$ of total liabilities. A negative impact was expected for Polish companies, as these companies have $75 \%$ of short-term liabilities. Hungarian and Slovenian companies are not meeting the results of previous studies, despite the fact that both economies are dominated by short-term debt. On the other hand, these companies possess of $45 \%$ of assets in the form of tangible fixed assets, so there is room for the positive effects of the variable.

In the case of a non-debt tax shield, the logic of the matter should have a negative effect, as argued, for example, by Wald (1999), Klapper et al. (2002), Hernádi and Ormos (2012), as the classic tax shield has a positive impact on the debt level and depreciation should be the exact opposite, which results in a negative impact on the debt level. However, in certain cases, a positive impact may be found, as found out, for example, by Delcoure (2007), Hernádi and Ormos (2010) and Mokhova and Zinecker (2013). According to the data in the Figure 2, we see that in almost all economies, for which the coefficient is statistically significant for this variable, a negative impact on the debt level was found. As a result, companies in Poland, Hungary, Romania, the Czech Republic and Austria are able to take advantage of depreciation and should therefore acquire more assets that can be depreciated and, if possible, assets that have higher depreciation rates. The only exception is Slovenian companies, where there is a positive link between the non-debt tax shield and the amount of debt. These companies have the highest share of depreciation to total assets (7\%), however this value is very far from the value of tangible fixed assets $(45 \%)$ and so the explanation cannot be used that these two groups of assets are almost equal and it is more advantageous for companies to use a collateral than non-debt tax shield. Therefore, the differences in tax regulations can be used as an explanation as we do not have detailed internal accounting of all Slovenian companies, in which the answer could probably be traced. 
The last variable, the effect of which on the indebtedness level was determined, the basic interest rate is. All results obtained for this variable are in harmony with the basic idea of the effect of funding external sources price. In Bulgaria, the Czech Republic, Slovakia and Slovenia, interest rates were very low. Slovenia and Slovakia had identical interest rates (socalled main refinancing operations) due to euro area membership. This rate decreased from 1 $\%$ to zero (which was the last three years) during the period under review. The Bulgarian basic interest rate and the Czech $2 \mathrm{~W}$ repo rate were not much better off with the development. In Bulgaria, the maximum was $0.22 \%$ (2011) and for the last three years $0 \%$. The Czech $2 \mathrm{~W}$ repo rate was $0.05 \%$ from 2012 to 2016 , rising to $1.75 \%$ in 2018. In a perspective of these developments, it is clear that in these economies, the price of debt financing has been very favorable and the resulting positive relationship between the interest rate and the debt level is expected. On the other hand, the negative impact of the interest rate on the debt level in Hungary, Romania and Poland is also predictable given the evolution of rates. The Polish reference rate reached its maximum in $2011-4.5 \%$. Since then, it has gradually decreased to $1.5 \%$ in 2015 (this rate remained until 2018). The Hungarian central bank basic rate reached higher values after the financial crisis, when it also reached its maximum in $2011-7 \%$. After that, it dropped significantly to $0.9 \%$ (since 2016). The Romanian reference interest rate was the highest in $2009-6.25 \%$. In 2015-2017, it was $1.75 \%$ and has risen again to $2.5 \%$ last year. Based on this description of the development, it is clear that in these three economies, the external source was more expensive, and therefore the debt was rather declining.

Figure 2: GMM model for medium-sized companies

\begin{tabular}{|c|c|c|c|c|c|c|c|}
\hline \multicolumn{8}{|c|}{ Total debt } \\
\hline & $\operatorname{DER}(-1)$ & ROA & $\mathrm{L} 2$ & SA & DEPR & GDP & IR \\
\hline $\mathrm{CZ}$ & $-0,001^{a}$ & $-1,429^{a}$ & & $-8,944^{a}$ & & $-17,208^{a}$ & \\
\hline PL & & $6,981^{\mathrm{a}}$ & $-0,002^{\mathrm{b}}$ & & $-1,169^{\mathrm{a}}$ & & $-11,869^{\mathrm{c}}$ \\
\hline $\mathrm{HU}$ & & & & $4,825^{\mathrm{a}}$ & $-2,485^{\mathrm{a}}$ & $110,924^{b}$ & \\
\hline BG & $0,044^{\mathrm{a}}$ & $5,824^{\mathrm{a}}$ & $-0,010^{\mathrm{c}}$ & & & & $179,672^{\mathrm{a}}$ \\
\hline RO & & & $-0,007^{\mathrm{a}}$ & $-13,015^{\mathrm{a}}$ & $-12,056^{\mathrm{a}}$ & & $-219,374^{a}$ \\
\hline \multicolumn{8}{|c|}{ Long-term } \\
\hline $\mathrm{CZ}$ & $0,003^{\mathrm{a}}$ & & $0,001^{\mathrm{a}}$ & & $-4,216^{a}$ & & $539,820^{\mathrm{a}}$ \\
\hline SK & $-0,219^{a}$ & $2,586^{\mathrm{b}}$ & & $2,772^{\mathrm{a}}$ & & $10,405^{\mathrm{a}}$ & $47,851^{\mathrm{c}}$ \\
\hline AT & $-0,287^{a}$ & $-5,194^{b}$ & & $8,263^{\mathrm{a}}$ & $-49,194^{a}$ & $64,775^{\mathrm{b}}$ & \\
\hline BG & $0,066^{\mathrm{a}}$ & $4,451^{\mathrm{a}}$ & & $5,271^{\mathrm{c}}$ & & $23,583^{\mathrm{a}}$ & \\
\hline \multicolumn{8}{|c|}{ Short-term debt } \\
\hline PL & $0,003^{\mathrm{a}}$ & & $-0,003^{a}$ & $-3,489^{b}$ & $-1,749^{a}$ & $13,671^{\mathrm{a}}$ & \\
\hline $\mathrm{HU}$ & $-0,008^{b}$ & $3,124^{\mathrm{b}}$ & $-0,004^{\mathrm{a}}$ & & $-4,549^{a}$ & & $-14,503^{\mathrm{a}}$ \\
\hline SI & & $1,217^{a}$ & & $4,391^{\mathrm{c}}$ & $12,959^{\mathrm{b}}$ & $12,902^{\mathrm{a}}$ & $406,219^{c}$ \\
\hline RO & $0,002^{\mathrm{a}}$ & $-11,812^{\mathrm{a}}$ & & $-5,491^{\mathrm{a}}$ & & $-28,451^{a}$ & $-129,210^{\mathrm{b}}$ \\
\hline
\end{tabular}

Source: author's calculations based on data from Orbis database Symbols: ${ }^{\mathrm{a}},{ }^{\mathrm{b}}$ and ${ }^{\mathrm{c}}$ indicate significance at $1 \%, 5 \%$, and $10 \%$.

The Figure 3 shows the results for large and very large companies operating in the manufacturing industry. The negative impact of profitability on the indebtedness level was found in Austrian, Czech, Romanian and Slovak companies. For all companies except Romanian, these coefficients are supported by the negative impact of GDP on debt levels. This means that if the economies prosper and grow, which all the mentioned economies meet (some of these economies grew at a very good pace - CZ, SK, RO), the profits of companies should also grow, which can be a profitable and cheap source of business activities financing. As for medium-sized companies, Romania has an unexpected negative impact. The explanation is the same for the given economies. Positive coefficients for Hungarian, Polish, Slovenian and Bulgarian companies are supported by positive coefficients for GDP. The results are the same as for medium-sized companies, and therefore, the explanations are the same. 
The relationship between the asset structure and the indebtedness level in large companies is the same as in medium-sized companies. Positive relationships were found in Hungarian, Bulgarian, Slovenian companies as it comes to long-term debt and in Slovak, Bulgarian and Austrian companies as it comes to short-term debt. The resulting relationships are interesting given that all of these economies are dominated by short-term debt, for which tangible fixed assets are not usually used as a collateral. In Slovakia, short-term liabilities account for $77 \%$ of liabilities, in Hungary $74 \%$, in Slovenia $65 \%$, in Bulgaria $66 \%$. On the other hand, the companies have a high stock of tangible fixed assets, which accounts for $44 \%$ of total assets in Slovakia, $28 \%$ in Hungary, $41 \%$ in Slovenia and $46 \%$ in Bulgaria. These percentages are relatively high and therefore the resulting impact can be positive. The only economy where a positive impact could be expected is Austria, where companies have only $30 \%$ of tangible fixed assets of total assets, but $81 \%$ of liabilities are long-termed. The only economy where the impact was negative is Romania. This is unexpected as $72 \%$ of liabilities are short-termed and $50 \%$ of assets are in the form of tangible fixed assets.

Regarding the impact of the non-debt tax shield on the debt level, Austrian, Slovenian, Romanian, Hungarian and Bulgarian companies showed a negative impact. As in the case of medium-sized companies, these companies benefit from depreciation, which reduces their indebtedness. At the same time, these companies should regularly buy and exchange assets having higher depreciation rates in order to achieve even higher benefits. A positive impact on the indebtedness level was found for Slovak companies. Due to the value of tangible fixed assets (44\% of total assets) and the value of depreciation (5\% of total assets) are very far apart, the explanation cannot be used that these two groups of assets are almost equal and it is more advantageous for companies to use a collateral than a non-debt tax shield. Therefore, differences in tax regulations could be taken as the explanation as we do not have detailed internal accounting of all Slovenian companies in which the answer could probably be traced.

Figure 3: GMM model for large and very large companies

\begin{tabular}{|c|c|c|c|c|c|c|c|}
\hline \multicolumn{8}{|c|}{ Total debt } \\
\hline & $\operatorname{DER}(-1)$ & ROA & $\mathrm{L} 2$ & SA & DEPR & GDP & IR \\
\hline SK & & & $-0,004^{b}$ & & & $-31,433^{b}$ & $56,508^{\mathrm{a}}$ \\
\hline $\mathrm{HU}$ & $0,502^{\mathrm{a}}$ & $3,414^{\mathrm{a}}$ & & $3,231^{\mathrm{a}}$ & $-4,676^{a}$ & & \\
\hline AT & $-0,199^{\mathrm{a}}$ & $-7,493^{b}$ & $-0,001^{\mathrm{a}}$ & & $-6,206^{\mathrm{a}}$ & & $26,383^{b}$ \\
\hline BG & $-0,008^{a}$ & & $-0,033^{\mathrm{a}}$ & $3,940^{\mathrm{a}}$ & & $3,902^{\mathrm{a}}$ & $43,456^{\mathrm{a}}$ \\
\hline \multicolumn{8}{|c|}{ Long-term } \\
\hline $\mathrm{CZ}$ & $0,536^{\mathrm{a}}$ & $-10,148^{b}$ & $-0,005^{\mathrm{b}}$ & & & $-1,836^{a}$ & $70,496^{\mathrm{a}}$ \\
\hline PL & $-0,004^{\mathrm{a}}$ & $6,447^{\mathrm{a}}$ & $-0,020^{\mathrm{a}}$ & & & $2,712^{\mathrm{b}}$ & $-5,852^{\mathrm{c}}$ \\
\hline SI & & & & $11,253^{\mathrm{b}}$ & $-4,223^{a}$ & $22,835^{\mathrm{a}}$ & \\
\hline RO & $0,004^{\mathrm{a}}$ & $-7,318^{b}$ & & $-1,258^{\mathrm{a}}$ & $-3,732^{\mathrm{a}}$ & & $-16,996^{\mathrm{a}}$ \\
\hline \multicolumn{8}{|c|}{ Short-term debt } \\
\hline SK & $0,012^{\mathrm{b}}$ & $-13,477^{a}$ & & $1,558^{\mathrm{a}}$ & $2,120^{\mathrm{a}}$ & & \\
\hline $\mathrm{HU}$ & $-0,144^{\mathrm{a}}$ & & $-0,001^{\mathrm{a}}$ & & & $11,577^{\mathrm{b}}$ & $-7,616^{\mathrm{b}}$ \\
\hline AT & & & & $14,244^{\mathrm{a}}$ & $-4,547^{b}$ & $-22,606^{\mathrm{a}}$ & \\
\hline SI & $0,007^{\mathrm{a}}$ & $2,589^{\mathrm{a}}$ & $0,010^{\mathrm{a}}$ & & $-2,406^{\mathrm{a}}$ & & $85,441^{\mathrm{a}}$ \\
\hline BG & & $3,787^{\mathrm{b}}$ & & $1,171^{\mathrm{b}}$ & $-1,226^{\mathrm{c}}$ & & $103,847^{\mathrm{a}}$ \\
\hline
\end{tabular}

Source: author's calculations based on data from Orbis database Symbols: ${ }^{\mathrm{a}},{ }^{\mathrm{b}}$ and ${ }^{\mathrm{c}}$ indicate significance at $1 \%, 5 \%$, and $10 \%$.

The results for the last change - the basic interest rate - are also very similar to the results for medium-sized companies. All the results obtained for this variable correspond with the basic idea considering the effect of external financial sources price. The positive impact of the interest rate on the debt level was found in the Czech Republic, Slovakia, Austria, Bulgaria and Slovenia. All economies except Austria have been explained for medium-sized companies, so there is no need to describe the same here. The results for Austria are special 
and therefore, they need to be analysed. We can assign Austria to Slovakia and Slovenia, as they also belong to the euro area and the development of the basic interest rate - main refinancing operations - was the same for these economies. This rate was $1 \%$ at the beginning of the period under review. In 2012, it fell to $0.75 \%$, in 2013 to $0.25 \%$, in the next two years it was $0.05 \%$ and for the last three years, this rate was even zero. In perspective of this development, it is clear that the price of debt financing was very favorable and the resulting positive relationship between the interest rate and the amount of debt is expected. As with medium-sized companies, large companies were found to have a negative impact of the level of basic interest rates on the level of indebtedness in Poland, Romania and Hungary. Given the development of basic interest rates, which is analysed for medium-sized companies, it is clear that in these three economies, the external source was more expensive and therefore, the debt was rather declining.

\section{Conclusion}

This research examined the financial structure of manufacturing companies operating in eight selected economies of Central and Eastern Europe - the Czech Republic, Slovakia, Poland, Hungary, Austria, Bulgaria, Romania and Slovenia. The companies were examined in terms of size. A total of 92,054 companies were analyzed, of which 76,810 were medium-sized companies and 15,244 were large and very large companies. The research was carried out for the period 2009-2018. The Generalized Method of Moments was used to determine the impacts of selected factors. The aim of the research was to find out whether profitability, liquidity, asset structure, non-debt tax shield, GDP, and interest rate have an effect on the amount of total, long-term and short-term debt. Within this goal, two research questions were formulated:

- Are there differences in impacts in terms of the different maturities of the used funding sources?

- What is the impact of the price of external sources of financing on the used sources of financing?

With three exceptions, the key findings show that the indebtedness level of companies operating in the manufacturing industry is most affected by non-corporate factors, especially in this case, by economic development and the level of the basic interest rate, which clearly prevails. These findings apply regardless of whether the company is of medium or large size. Of course, the impact varies, but we can say that the direction of the impact of the interest rate on the debt level follows the basic logic - the higher the cost of acquiring an external resource, the less demand for such resources is. Therefore, the basic interest rate has a positive impact on the indebtedness level in the Czech Republic, Slovakia, Austria, Slovenia and Bulgaria as these economies were supported by national central banks and interest rates were zero or close to zero for most of the period under review. Contrary to that, Poland, Hungary and Romania belong to the economies with higher rates, which is why the impact of the interest rate on the debt level is negative. For companies, these findings mean that certain employees should monitor macroeconomic forecasts and central bank statements and, based on this information, incorporate forecasts into their models. Once the company learns how to work with the results of this research, it would be able to plan better how to use own and debt financing sources and in what ratio.

As for the remaining variables, medium and large companies were very similar in these results as well. The past indebtedness level and liquidity in both cases reached very low coefficients, so it is not possible to speak about any significant influence, but rather about the direction the results indicated. For both types of companies, the positive impact of past 
indebtedness slightly prevails, which means that if debt financing has been used in the past, it will not be different in the future. On the contrary, liquidity was dominated by negative effects on the indebtedness level.

Profitability had a negative impact on Czech, Romanian and Austrian companies alike. For Czech and Romanian companies, these results were supported by GDP results, which were also negative. In times of economic prosperity and higher profitability, these companies use own resources, which are cheaper and more convenient. On the contrary, in the remaining economies, profitability of the companies and the GDP growth rate have had a positive impact on the level of indebtedness, which means the exact opposite, namely, that when economies thrive and companies thrive and their profits grow, companies tend to use the debt financing more. None of the identified impacts is a surprise as all economies prospered for most of the period under review. Only the beginning of the period was marked by the ending financial crisis. Although, considering the world economy, several events took place, they did not much influence the economies we monitored.

In terms of assets mix, short-term debt dominated in all companies except Austria, regardless of size (on average over $71 \%$ of total liabilities). For Austrian companies, long-term debt was clearly dominated (on average over $90 \%$ of total liabilities). The equipment of tangible fixed assets used as a collateral was also high (on average over $40 \%$ of total assets). In almost all cases, the resulting relationships also corresponded to this - they were positive for long-term debt, negative for short-term debt and more or less negative for total debt, given that shortterm debt prevailed in total debt.

The impact of the non-debt tax shield on the indebtedness level is almost in all cases negative, which means that companies can take advantage of depreciation and should therefore acquire more assets that can be depreciated and, if possible, assets that depreciate at higher rates to achieve greater benefits. Slovenian medium-sized and Slovak large companies were exceptions, for which a positive impact of the non-debt tax shield on the level of debt was found. These companies have a higher share of tangible fixed assets over depreciation, so the explanation that these two groups of assets are almost equal and it is more advantageous for companies to use a collateral than a non-debt tax shield cannot be used. Therefore, the differences in tax regulations could be the explanation as we do not have detailed internal accounting of all Slovenian companies in which the answer could probably be traced.

\section{Acknowledgement}

This article was supported by SGS/16/2020 Influence of selected internal and macroeconomic determinants on financial structure of companies in selected countries of Central and Eastern Europe.

\section{References}

[1] ACEDO-RAMÍREZ, M. A. and F. J. RUIZ-CABESTRE, 2014. Determinants of capital structure: United Kingdom versus continental European countries. Journal of International Financial Management \& Accounting, 25(3), 237-270. ISSN 1467-646X.

[2] ARELlANO, M. and S. BOND, 1991. Some Tests of Specification for Panel Data: Monte Carlo Evidence and an Application to Employment Equations. Review of Economic Studies, 58(2), 277-297. ISSN 1467-937X. 
[3] ARELLANO, M. and O. BOVER, 1995. Another look at the instrumental variable estimation of error-components models. Journal of Econometrics, 68, 29-51. ISSN 03044076.

[4] AULOVÁ, R. and T. HLAVSA, 2013. Capital structure of agricultural businesses and its determinants. Agris on-line Papers in Economics and Informatics, 5(2), 23-36. ISSN 1804-1930.

[5] BASTOS, D. D. et al., 2009. Determinants of capital structure of publicly-traded companies in Latin America: The role of institutional and macroeconomic factors. Journal of International Finance and Economics, 9(3), 24-39. ISSN 1086-7376.

[6] BAUER, P., 2004. Determinants of capital structure: Empirical evidence from the Czech Republic. Czech Journal of Economics and Finance, 54(1-2), 2-21. ISSN 2464-7683.

[7] BOKPIN, G. A., 2009. Macroeconomic development and capital structure deci-sions of firms: Evidence from emerging market economies. Studies in Economics and Finance, 26(2), 129-142. ISSN 1555-6336.

[8] BLUNDELL, R. and S. BOND, 1998. Initial conditions and moment restrictions in dynamic panel data models. Journal of Econometrics, 87(1), 115-143. ISSN 0304-4076.

[9] BREALEY, R. A., S. W. MYERS and F. ALLEN 2011. Principles of Corporate Finance, 10th Ed. New York: McGraw-Hill. ISBN 978-0077404895.

[10] CAMARA, O., 2012. Capital Structure Adjustment Speed and Macroeconomic Conditions: U.S MNCs and DCs. International Research Journal of Finance and Economics, 84, 106-120. ISSN. 1450-2887.

[11] ÇEKREZI, A., 2013. The determinants of capital structure: Evidence from Albania. Academic Journal of Interdisciplinary Studies, 2(9), 370-376. ISSN 2281-4612.

[12] CHENG, S. R. and C. Y. SHIU, 2007. Investor protection and capital structure: International evidence. Journal of Multinational Financial Management, 17(1), 30-44. ISSN: 1042-444X.

[13] ČRNIGOJ, M. and D. MRAMOR, 2009. Determinants of capital structure in emerging European economies: Evidence from Slovenian firms. Emerging Markets Finance \& Trade, 45(1), 72-89. ISSN 1558-0938.

[14] DE HAAS, R. and M. PEETERS, 2006. The dynamic adjustment towards target capital structures of firms in transition economies. Economics of Transition, 14(1), 133-169. ISSN 2577-6983.

[15] DE JONG, A. et al., 2008. Capital structure around the world: The roles of firm- and country-specific determinants. Journal of Banking \& Finance, 32(9), 1954-1969. ISSN: 0378-4266.

[16] DELCOURE, N., 2007. The determinants of capital structure in transitional economies. International Review of Economics \& Finance, 16(3), 400-415. ISSN: 1059-0560.

[17] FRIEDER, L. and R. MARTELL, 2006. On capital structure and the liquidity of a firm's stock. Purdue University, Krannert School of Management. Retrieved from https://ssrn.com/abstract=880421.

[18] GAJUREL, D. P., 2006. Macroeconomic influences on corporate capital structure. Avalaible from SSRN: https://papers.ssrn.com/sol3/papers.cfm?abstract_id=899049. 
[19] HANOUSEK, J. and A. SHAMSHUR, 2011. A stubborn persistence: Is the stability of leverage ratios determined by the stability of the economy? Journal of Corporate Finance, 17(5), 1360-1376. ISSN 0929-1199.

[20] HERNÁDI, P. and M. ORMOS, 2010. Capital structure and its choice in Central and Eastern Europe. Acta Oeconomica, 62(2), 229-263. ISSN 1804-2112.

[21] HERNÁDI, P. and M. ORMOS, 2012. What Managers Think of Capital Structure and How They Act: Evidence from Central and Eastern Europe. Baltic Journal of Economics, 12(2): 47-71. ISSN 1406-099X.

[22] JAGANNATHAN, R., G. SKOULAKIS and Z. WANG, 2002. Generalized Method of Moments: Applications in Finance, Journal of Business and Economic Statistics, 20(4), 470-481.

[23] JÕEVEER, K., 2013. Firm, country and macroeconomic determinants of capital structure: Evidence from transition economies. Journal of Comparative Economics, 41(1), 294-308. ISSN: 0147-5967.

[24] KAYO, E. K. and H. KIMURA, 2011. Hierarchical determinants of capital structure. Journal of Banking \& Finance, 35(2), 358-371. ISSN: 0378-4266.

[25] KLAPPER, L. F. et al., 2002. Small- and Medium-Size Enterprise Financing in Eastern Europe. World Bank Policy Research Working Paper No. 2933.

[26] LIPSON, M. L. and S. MORTAL, 2009. Liquidity and capital structure. Journal of Financial Markets, 12(4), 611-644. ISSN 1386-4181.

[27] MATEEV, M. et al., 2013. On the determinants of SME capital structure in Central and Eastern Europe: A dynamic panel analysis. Research in International Business and Finance, 27(1), 28-51. ISSN: 0275-5319.

[28] MICHAELAS, N. et al., 1999. Financial policy and capital structure choice in U.K. SMEs: Empirical evidence from company panel data. Small Business Economics, 12(2), 113-130. ISSN 1573-0913.

[29] MODIGLIANI, F. and M. H. MILLER, 1958. The Cost of Capital, Corporation Finance and the Theory of Investment. American Economic Association, 48(3), 261-297. ISSN 0002-8282.

[30] MOKHOVA, N. and M. ZINECKER, 2013. The determinants of capital structure: The evidence from the European Union. Acta Universitatis Agriculturae et Silvicul-turae Mendelianae Brunensis, 61(7), 2533-2546. ISSN 2464-8310.

[31] MORELLEC, E., 2001. Asset liquidity, capital structure, and secured debt. Journal of Financial Economics, 61(2), 173-206. ISSN 0304-405X.

[32] MURSALIM, M. M. and H. KUSUMA, 2017. Capital structure determinants and firms' performance: Empirical evidence from Thailand, Indonesia and Malaysia. Polish Journal of Management Studies, 16(1), 154-164. ISSN 2081-7452.

[33] MYERS, S. C., 1984. The capital structure puzzle. Journal of Finance, 39, 575-592. ISSN 1540-6261.

[34] MYERS, S. C., 2001. Capital structure. The Journal of Economic Perspectives, 15(2), 81-102. ISSN 0895-3309.

[35] MYERS, S. C. and R. G. RAJAN, 1998. The Paradox of Liquidity. The Quarterly Journal of Economics, 113(3), 733-771. ISSN 1531-4650. 
[36] NIVOROZHKIN, E., 2002. Capital structures in emerging stock markets: The case of Hungary. The Developing Economies, 40(2), 166-187. ISSN 1746-1049.

[37] NIVOROZHKIN, E., 2005. Financing choices of firms in EU accession countries. Emerging Markets Review, 6(2), 138-169. ISSN 1566-0141.

[38] ONOFREI, M. et al., 2015. Determinant Factors of Firm Leverage: An Empirical Analysis at Iasi County Level. Procedia Economics and Finance, 20, 460-466. ISSN 2212-5671.

[39] PINKOVÁ, P., 2012. Determinants of capital structure: Evidence from the Czech automotive industry. Acta Universitatis Agriculturae et Silviculturae Mendelianae Brunensis, 60(7), 217-224. ISSN 2464-8310.

[40] PRĘDKIEWICZ, K. and P. PRĘDKIEWICZ, 2015. Chosen determinants of capital structure in small and medium-sized enterprises - Evidence from Poland. Finanse, Rynki Finansowe, Ubezpieczenia, 74(2), 331-340. ISSN 2450-7741.

[41] PRŮCHA, I. R., 2014. Instrumental Variables/Method of Moments Estimation. In Fisher, M. M. \& P. Nijkamp (Rd.), Handbook of Regional Science. Heidelberg: Springer, s. 1597-1617. ISBN 978-3-642-23429-3.

[42] RAJAN, R. G. and L. ZINGALES, 1995. What do we know about capital structure? Some evidence from international data. The Journal of Finance, 50(5), 1421-1460. ISSN 1540-6261.

[43] REHMAN, Z. U., 2016. Impact of macroeconomic variables on capital structure choice: A case of textile industry of Pakistan. The Pakistan Development Review, 55(3), 227239. ISSN 0030-9729.

[44] RIAZ, F. et al., 2014. Macroeconomic conditions and firm's choices of capital structure: Evidence from Pakistan's manufacturing sectors. Middle-East Journal of Scientific Research, 19(4), 521-531. ISSN 1990-9233.

[45] RŮČKOVÁ, P., 2015a. Impact of fixed assets share and profitability on use of debt sources of companies in the building industry in V4 countries. Acta academica karviniensia, 15(2), 122-135. ISSN 2533-7610.

[46] RŮČKOVÁ, P., 2015b. Impact of liquidity and profitability on use of debt finance sources of companies in manufacturing industry in V4 countries. Acta academica karviniensia, 15(3), 69-79. ISSN 2533-7610.

[47] RŮČKOVÁ, P., 2017. Evaluation of profitability impact on selection of financing sources under conditions in Visegrád Group countries in the field of power engineering. Scientific Papers of the University of Pardubice, D(39), 140-150. ISSN 1804-8048.

[48] ROODMAN, D., 2009. How to do xtabond2: An introduction to difference and system GMM in Stata, The Stata Journal, 9(1), 86-136. ISSN 1536-8734.

[49] SALEHI, M. and N. B. MANESH, 2012. A study of the roles of firm and country on specific determinates in capital structure: Iranian evidence. International Management Review, 8(2), 51-62. ISSN 1551-6849.

[50] SHLEIFER, A. and R. W. VISHNY, 1992. Liquidation values and debt capacity: A market equilibrium approach. The Journal of Finance, 47(4), 1343-1366. ISSN 15406261 . 
[51] SONG, H. S., 2005. Capital structure determinants - An empirical study of Swedish companies. Working paper No. 25, The Royal Institute of Technology, Centre of Excellence for Science and Innovation Studies.

[52] TITMAN, S. and R. WESSELS, 1988. The determinants of capital structure choice. The Journal of Finance, 43, 1-19. ISSN 1540-6261.

[53] TOY et. al., 1974. A comparative international study of growth, profitability, and risk as determinants of corporate debt ratios in the manufacturing sector. The Journal of Financial and Quantitative Analysis, 9(5), 875-886. ISSN 1756-6916.

[54] ULLAH, S. et al., 2018. Dealing with Endogeneity Bias: The Generalized Methods of Moments (GMM) for panel data, Industrial Marketing Management, 71, 69-78. ISSN 0019-8501.

[55] VO, X. V., 2017. Determinants of capital structure in emerging markets: Evidence from Vietnam. Research in International Business and Finance, 40, 105-113. ISSN: 02755319.

[56] WALD, J. K., 1999. How firm characteristics affect capital structure: An international comparison. The Journal of Financial Research, 22(2), 161-187. ISSN1475-6803.

[57] WEILL, L., 2004. What determinants leverage in transition countries? Czech Journal of Economics and Finance, 54(5-6), 234-242. ISSN 2464-7683.

[58] WILLIAMSON, O. E., 1988. Corporate finance and corporate governance. The Journal of Finance, 43(3), 567-591. ISSN 1540-6261.

[59] YINUSA, O. G. et al., 2017. Macroeconomic determinants of capital structure of firms: Evidence from Nigeria. Journal of Knowledge Globalization, 9(2), 1-21. ISSN: 19387008. 